\title{
Potensi Ekstrak Tanaman Sebagai Pestisida Alami Di Desa Salu Kecamatan Miomafo Barat Kabupaten TTU
}

\author{
Jefry Presson ${ }^{1)}$,Gebhardus D. Gelyaman ${ }^{1)}$,Yohana Ivana Kedang ${ }^{1)}$,Sefrinus Maria Dolfi Kolo ${ }^{1)}$, \\ Regina Seran ${ }^{1)}$,Eduardus Edi ${ }^{1)}$,Maria Magdalena Kolo ${ }^{1)}$ \\ ${ }^{1)}$ Program Studi Kimia, Universitas Timor, Indonesia. \\ Pos-el: pressontimor@gmail.com
}

\begin{abstract}
Abstrak
Pengabdiandenganjudul potensi ekstrak tanaman sebagai pestisida alami di desa Salu kecamatan Miomafo Barat kabupaten TTU telah dilaksanakan pada Bulan November 2018. Tujuan dari pengabdian ini adalah memberikan pengetahuan tentang cara meningkatkan produksi pangan melalui pemberantasan hama, memberikan pengetahuan tentang keunggulan pestisida alami dibandingkan pestisida sintetis, dan membuat ekstrak daun sirsak sebagai pestisida alami.Target utama dari kegiatan ini adalah para petani yang dilakukan melalui ceramah, distribusi brosur, dan pelatihan pembuatan produk. Kegiatan pengabdian ini dilakukan dalam 3 sesi. Sesi pertama merupakan sosialisasi cara meningkatkan produksi pangan melalui pemberantasan hama. Sesi kedua merupakan sosialisasi keunggulan pestisida alami dibandingkan pestisida sintetis. Pembuatan ekstrak sirsak sebagai pestisida alami menjadi sesi ketiga yang menutup semua rangkaian kegiatan pengabdian. Selain memberikan pertanyaan, para petani juga memberikan pengalaman pribadi yang berguna bagi pengembangan ilmu pengetahuan. Adanya koordinasi pada pembuatan ekstrak sirsak mengindikasikan tingginya antusiasme para petani di Desa Salu terhadap kegiatan pengabdian ini. Produk akhir pada kegiatan ini adalah ekstrak daun sirsak yang siap diaplikasikan pada tanaman.
\end{abstract}

Kata Kunci: (pestisida alami, ekstrak daun sirsak, hama, pengabdian).

\begin{abstract}
Devotion with the title of potential plant extracts as natural pesticides in Salu village, Miomafo Barat district, TTU district was held in November 2018. The purpose of this service was to provide knowledge on how to increase food production through eradicating pests, providing knowledge about the advantages of natural pesticides compared to synthetic pesticides, and make soursop leaf extract as a natural pesticide. The main target of this activity is the farmers who are conducted through methods of lecture, brochure distribution, and product manufacturing training. This service activity was conducted in 3 sessions. The first session was a socialization of ways to increase food production through eradicating pests. The second session is a socialization of the advantages of natural pesticides compared to synthetic pesticides. Making soursop extract as a natural pesticide is the third session that closes all the series of devotion. In addition to providing questions, farmers also provide personal experiences that are useful for the development of science. The coordination of the making of soursop extract indicates the high enthusiasm of the farmers in Salu village towards this devotion. The final product in this activity is soursop leaf extract which is ready to be applied to plants.
\end{abstract}

Keywords: (natural pesticides, soursop leaf extract, pests, devotion).

\section{PENDAHULUAN}

Indonesia memiliki keragaman flora yang sangat besar. Lebih dari 400 ribu jenis tumbuhan telah teridentifikasi dan 10 ribu di antaranya mengandung metabolit sekunder yang potensial sebagai bahan baku pestisida alami. Hasil-hasil penelitian menunjukkan beberapa senyawa metabolit sekunder dapat mengendalikan populasi serangga hama. Senyawa metabolit sekunder tersebut dalam melindungi tanaman dapat berperan sebagaian 
tifitopatogenik (anti biotik pertanian), fitotoksik yang mengatur pertumbuhan tanaman (fitotoksin, hormon, dan sejenisnya), dan bahan aktif terhadap serangga (hormon serangga, feromon, antifi dan, repelen, atraktan, dan insektisida). Pestisida alami jenis insektisida telah digunakan hampir 2000 tahun di Cinakuno, Mesir, Yunani, dan India (P Long dkk., 2006). Bahkan di Amerika Serikat dan beberapa Negara Eropa, insektisida alami secara luas digunakan sebelum penemuan organo klorin dan insektisida organo fosfat pada akhir 1930 dan awal 1940 (Isman, 2006)

Penemuan dikloro difenil trikloroetan (DDT) pada tahun 1939 telah menyebabkan manusia beralih pada penggunaan pestisida sintetis. Pestisida ini telah terbukti dapat meningkatkan produksi pangan dalam satu abad terakhir. Namun, survey dari berbagai Negara mengatakan bahwa pestisida sintetis memiliki efek buruk terhadap tanah, perairan dan efek toksik terhadap biota kehidupan (Nicolopoulou-stamati, 2016). Kebijakan internasional hasil konferensi PBB tentang Lingkungan dan Pembangunan (diadakan di Rio de Janeiro, Brasil pada tahun 1992) dan kebijakan nasional penggunaan pestisida nabati sebagai komponen utama dalam program pengendalian hama terpadu (PeraturanPemerintah No. 6 tahun 1995), telah mengindikasikan penggunaan pestisida alami atau pestisida botani atau pestisi dan nabati.

Keluarga tumbuhan Annonaceae seperti Annona muricata L. sejak tahun 1980 telah menarik banyak perhatian karena mengandung acetogenin yang berperan sebagai anti feeding (Di Toto Blessing dkk., 2010). Acetogenin adalah senyawa poliketida dengan struktur 30-32 rantai karbon tidak bercabang yang terikat pada gugus 5-methyl-2-furanon. Rantai furanone dalam gugus hidrofuranon pada C-23 memiliki aktifitas sitotoksik, dan derivatecetogenin yang berfungsi sitotoksik adalah asimicin, bulatacin, dan squamocin(Ragasa dkk., 2012).

Desa Salu merupakan daerah pertanian hijau yang produktif dan terus memberikan pasokan pangan ke Kota dan sekitarnya. Sebagian petani menggunakan pestisida sintetis dan sebagian petani memilih tidak menggunakan apapun untuk mengendalikan hama. Oleh karena itu, pengabdian kepada masyarakat dengan tema potensi ekstrak tanaman sebagai pestisida alami di Desa Salu Kecamatan Miomafo Barat Kabupaten TTU penting untuk dilakukan.

\section{METODE}

Metode pengabdian yang digunakan adalah metode ceramah, pembagian brosur dan pelatihan pembuatan ekstrak sirsak. Brosur dapat dilihat pada gambardi bawah ini. 
Gambar 1. Brosur pestisida alami dari ekstrak daun sirsak

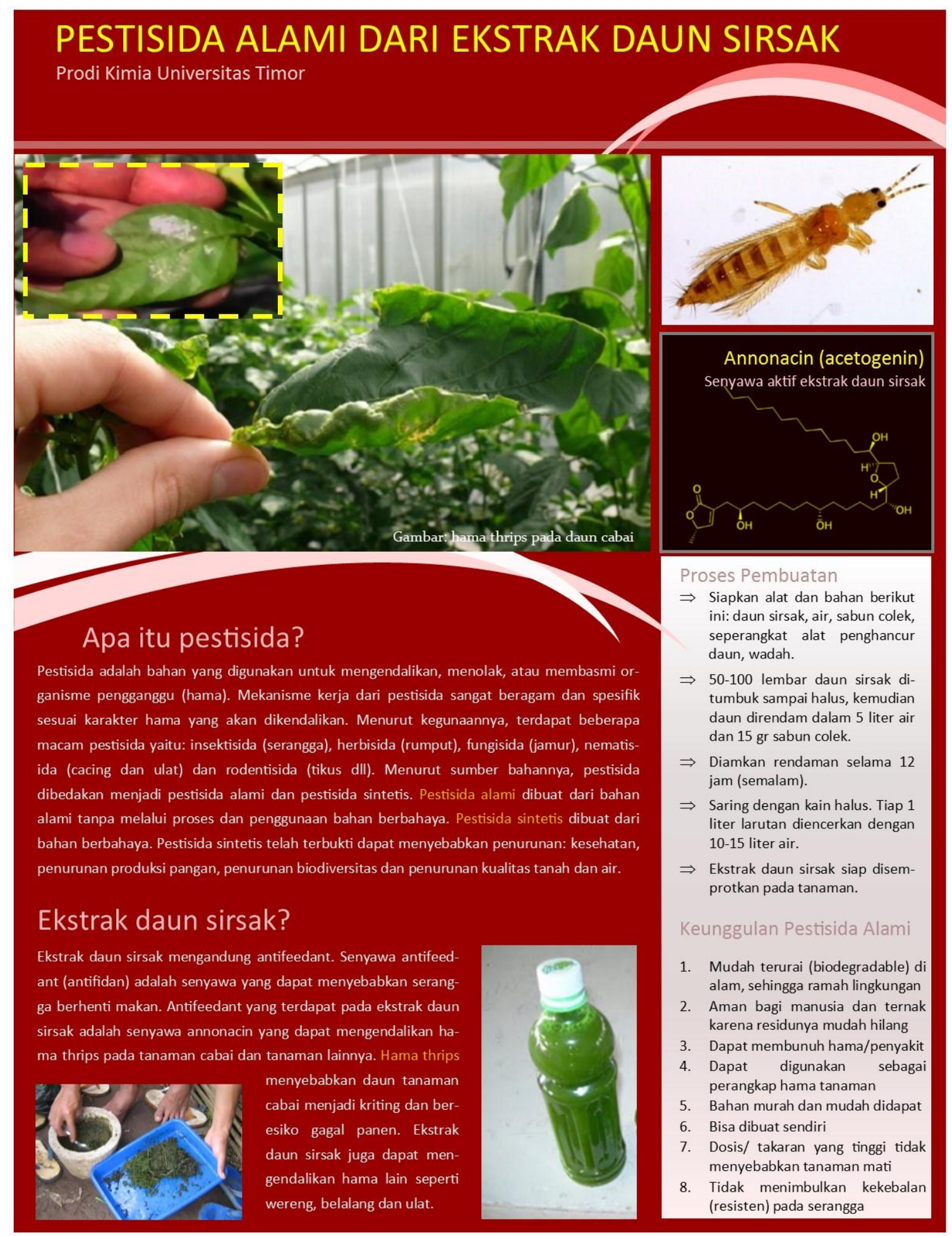




\section{HASIL DAN PEMBAHASAN}

Pengabdian masyarakat yang telah dilaksanakan oleh dosen-dosen dari prodi kimia Universitas Timor ini berlangsung selama 1 hari di DesaSalu. Kegiatan yang dihadiri 28 orang ini dibagi kedalam 3 sesi yang dapat dilihat pada tabel 1.

Tabel 1: Jadwal sesi pengabdian

\begin{tabular}{|c|l|c|}
\hline Sesi & \multicolumn{1}{|c|}{ Jenis kegiatan } & waktu \\
\hline Sesi 1 & $\begin{array}{l}\text { sosialisai cara meningkatkan produksi pangan } \\
\text { melalui pemberantasan hama }\end{array}$ & $09.00-10.00$ \\
\hline Sesi 2 & $\begin{array}{l}\text { sosialisasi keunggulan petisida alami } \\
\text { dibandingkan petisida sintetis }\end{array}$ & $11.00-12.00$ \\
\hline Sesi 3 & $\begin{array}{l}\text { pembuatan ekstrak sirsak sebagai pestisida } \\
\text { alami }\end{array}$ & $13.00-16.00$ \\
\hline
\end{tabular}

Pengabdian masyarakat yang dilaksanakan di Desa Salu dengan peserta dari para petunia dalah bentuk perwujudan dari kewajiban menjalankan tridarma oleh Dosen di tingkat Universitas. Kegiatan ini dilakukan berdasarkan pengamatan umum bahwa adanya kegagalan panen oleh hama. Disamping itu, pengamatan lain yang tidak kalah penting adalah maraknya penggunaan pestisida sintetik yang beredar pesat oleh para petani di Desa Salu. Tentu ini adalah halurgen yang harus disikapi secara serius, mengingat banyaknya dampak negatif yang timbulkan oleh pestisida sintetis.

Pengabdian ini dilakukan di rumah warga dengan 3 pembagian waktu. Pada sesi pertama, jenis kegiatan yang dilakukan adalah sosialisasi cara menigkatkan produksi pangan melalui pemberantasan hama. Kegiatan ini dilakukan dengan metode percakapan 2 arah, dimana selain dosen memberikan materi, dosen juga memberikan kesempatan bagi para petani untuk bertanya, sharing pengalaman, maupun mengemukakan masalah yang terjadi di lapangan. Sesi kegiatan ini memberikan pengetahuan kepada para petani tentang, macammacam hama, cara mengontrol hama, dan pentinganya penggunaan pestisida untuk mengontrol hama. Sesi kegiatan ini dapat dikatakan sukses yang terlihat dari banyaknya pertanyaan oleh para petani.

Jenis kegiatan pada sesi 2 yang dilakukan adalah sosialisasi keunggulan pestisida alami dibandingkan pestisida sintetis. Kegiatan ini juga dilakukan dengan metode percakapan 2 arah. Sesi kegiatan ini memberikan pengetahuan kepada para petani tentang macam-macam pestisida alami, mekanisme kerja, sasaran dari pestisida alami, cara penggunaan (dosis), dan keunggulan pestisida alami termasuk dampak jangka panjang yang ditimbulkan. Sesi kegiatan ini dapat dikatakan sangat sukses. Hal ini terlihat dari tinggin yang antusiasme para petani.

Jenis kegiatan pada sesi ke 3 yang dilakukan adalah pembuatan ekstrak sirsak sebagai pestisida alami. Kegiatan dilakukan dengan cara petani didorong lebih aktif serta dapat berkoordinasi antar sesama.Pada sesi ini, para petani diberikan cara membuat ekstrak sirsak mulai dari pengumpulan daun sampai menjadi produk berupa ekstrak daun sirsak. Para petani terlihat sangat antusias pada sesi ini. Hal ini terbukti dari tingginya keaktifan dan tingkat koordinasi antar individu.

Semua sesi kegiatan ini berakhir pada jam 16.30 Wita dengan menghasilkan produk ekstrak daun sirsak. Sayangnya, kegiatan ini tidak berakhir dengan aplikasi pada tanaman 
sasaran, karena ekstrak daun sirsak butuh didiamkan selama 1 malam agar dapat digunakan/ diaplikasikan ketanaman sasaran. Selain itu, efek panjang penggunaan ekstrak daun sirsak tidak dapat dilihat dalam waktu singkat.

\section{SIMPULAN}

Berdasarkan hasil pengabdian yang telah dilakukan maka dapat disimpulkan :

1. Para petani di Desa Salu telah mengetahui cara meningkatkan produksi pangan melalui pemberantasan hama.

2. Para petani di Desa Salu telah menyadari berbagai keunggulan yang diberikan oleh pestisida alami dibandingkan pestisida sintetis.

3. Para petani di Desa Salu telah membuat ekstrak sirsak sebagai pestisida alami.

\section{DAFTAR PUSTAKA}

Di Toto Blessing, L., Álvarez Colom, O., Popich, S., Neske, A., \& Bardón, A. (2010). Antifeedant and toxic effects of acetogenins from Annona montana on Spodoptera frugiperda. Journal of Pest Science (Vol. 83). https://doi.org/10.1007/s10340-010-02990

Isman, M. (2006). Botanical Insecticides, Deterrents, And Repellents In Modern Agriculture And An Increasingly Regulated World. Annual review of entomology (Vol. 51). https://doi.org/10.1146/annurev.ento.51.110104.151146

Nicolopoulou-stamati, P. (2016). Chemical Pesticides and Human Health: The Urgent Need for a New Concept in Agriculture, 4(July), 1-8. https://doi.org/10.3389/fpubh.2016.00148

P Long, S., A Ainsworth, E., Leakey, A., Nösberger, J., \& R Ort, D. (2006). Food for Thought: Lower-Than-Expected Crop Yield Stimulation with Rising CO2 Concentrations. Science (New York, N.Y.) (Vol. 312 ). https://doi.org/10.1126/science.1114722

Ragasa, C., Geneveve, S., Torres, O., \& Ming-Jaw and Shen Chien-Chang, D. (2012). Acetogenins from Annona muricata. Pharmacognosy Journal (Vol. 32). https://doi.org/10.5530/pj.2012.32.7 